\title{
DNA methylation dynamics during oocyte and embryo development and its association with environmental induced alterations
}

\author{
T. Fair ${ }^{1}$ \\ School of Agriculture and Food Sciences, University College Dublin, Dublin, Ireland.
}

\begin{abstract}
Epigenetic mechanisms are fundamental to successful gametogenesis and development. The fertilized egg undergoes global DNA demethylation to facilitate remodelling from two differentiated gametespecific states to a pluripotent embryonic state. Maintenance of appropriate levels of DNA methylation during preimplantation development is essential to embryo viability. Recent advances in epigenetic research have highlighted the susceptibility of foetal epigenetic programming to maternal health and nutritional status, particularly, at the time of conception. There is much evidence that maternal stress impacts on ovarian function, leading to compromised oocytes presented for fertilization in a suboptimal environment. Similarly, declining fertility has become a substantive issue in western countries, where it is primarily associated with high mean ages at childbearing. Thus the use of assisted reproduction technologies (ART) interventions to overcome low fertility is increasing steadily across the globe. In addition, the use of prolonged in vitro culture following the removal and storage of oocytes and/or ovarian tissue in advance of cancer treatment, or to circumvent ovarian aging, is increasing rapidly. ART is associated with compromised pre and post -natal outcomes, including premature birth, low birth weight, congenital abnormalities and elevated risk of epigenetic disorders. There is extensive evidence from studies in cattle that embryos produced by conventional ART protocols are susceptible to errors in epigenetic programming. The present review discusses the impact of intrinsic physiological status and external environments on oocyte and embryo DNA methylation with regard to data available from mouse, human and bovine models.
\end{abstract}

Keywords: epigenetic, oocyte, embryo, mammals.

\section{Introduction}

Genomic imprinting is an epigenetic process, which enables parent-of-origin expression of a cohort of mammalian genes (Fowden et al., 2006). The correct dosage of imprinted gene expression has been shown to be critically important to embryonic growth, development, placental function and postnatal behaviour and metabolism (Reik and Walter, 2001; Davies et al., 2005; Smith et al., 2006). Parent-of-origin expression of imprinted genes is facilitated through asymmetrical epigenetic marks on either the maternal or paternal allele. Generally, imprinted genes are arranged in clusters containing differentially marked, $\mathrm{CpG}$ rich domains, known as differentially methylated regions (DMRs); the most extensively studied of these marks is DNA methylation
(Lucifero et al. 2004). Mammalian DNA methylation patterns required for genomic imprinting are subject to periods of dynamic reprogramming during development and are established at different developmental time points, depending on whether they are transmitted through the male or the female germline. Paternal DMRs acquire their methylation marks prior to birth in the prospermatagonia (Davis et al., 2000; Li et al., 2004); while DNA methylation marks at maternal DMRs are established postnatally in the growing oocyte (Hiura et al., 2006). Epigenetic reprogramming involves DNA methylation erasure and re-establishment at two points in the life cycle, firstly after fertilization in the zygote, and secondly in primordial germ cells (PGCs), which are the direct progenitors of sperm or oocyte. Following fertilization, global DNA demethylation occurs in the zygote to facilitate remodelling from two distinct differentiated gamete-specific states to a pluripotent embryonic state (Hales et al., 2011; Torres-Padilla and Ciosk, 2013). The epigenetic signature inherited from the gametes (excepting the parental imprints) is erased and developmental totipotency is restored. In the PGCs, parental imprints are erased and de novo establishment of new methylation landscapes that are different between male and female germlines restore germline developmental potential (Seisenberger et al., 2013). There is extensive evidence in cattle, human and laboratory model species that intrinsic physiological status and external environments, such as assisted reproductive technologies (ART), can dramatically alter the epigenetic landscape of gamete, embryonic, foetal and adult tissues, leading to impaired function/ adverse health outcomes in adult life. The mechanisms and implications with regard to data available from mouse, human and bovine models are reviewed.

DNA methylation dynamics during epigenetic reprogramming in the germline and preimplantation embryos

\section{DNA methylation erasure}

Recent studies have started to elucidate how global demethylation in the zygote and PGCs is orchestrated. It appears that active demethylation occurs on the paternal genome in one-cell embryos (Maher and Reik, 2000; Oswald et al., 2000) and passive demethylation occurs on the maternal genome from the two-cell until the blastocyst -stage (Reik et al., 2001). It would appear that the major wave of genomewide demethylation occurs between fertilization and the twocell stage in humans with only subtle changes in DNA methylation levels occurring thereafter (Guo et al., 2014). In mouse, the most important period of demethylation occurs at the zygote stage, followed by gradual demethylation until the blastocyst stage (Smith et al., 2012). In both human and mouse, demethylation of the paternal genome occurs much faster than that of the maternal genome (Guo et al., 2014; Smith et al., 2014). Several models for active DNA demethylation have been proposed (Morgan et al., 2005; Wu and Zhang, 2010): Active demethylation mediated by the teneleven-translocation (TET) family member, Tet3, appears to 
be important for both (Guo et al., 2014; Smith et al., 2014), while Base Excision Repair (BER) pathway may also be important (Xu and Walsh, 2014). Maintenance of appropriate levels of DNA methylation during preimplantation embryo development is essential for the viability of embryos (Barton et al., 2001). As well as the marked allele being resistant to demethylation, equally important appears to be the ability of the unmarked allele to resist de novo methylation following implantation (Proudhon et al., 2012; Rutledge et al., 2014).

PGCs arise in the epiblast of the developing embryo (Ginsburg et al., 1990), where they inherit the somatic epigenetic traits that are present in the cells of the epiblast at this time, including significant levels of global DNA methylation (Seki et al., 2005; Ohinata et al., 2009). Therefore, PGCs need to reprogramme from a somatic profile into that of germ cells that will give rise to the gametes, with the capacity to form the totipotent zygote in the next generation. DNA methylation is globally erased during migration of PGCs towards the genital ridge. Epigenetic reprogramming in PGCs requires remodelling of the chromatin structure, global changes in the transcriptional landscape and the resetting of imprint DNA methylation marks. It is essential for the development of the next generation that the parental imprints are erased in PGCs and that new imprints are established that reflect the gender of the embryo. These imprints are then maintained in the gametes derived from the PGCs and will contribute to the epigenome of the future zygote (Seisenberger et al., 2013).

The mechanisms involved in PGC demethylation have been difficult to elucidate, due to the inaccessible nature of PGCs. Up until recently, studies in mouse focused on the period between E11.5 and E13.5 (Reik et al., 2001; Hajkova et al., 2002). The short duration of this period, specifically the low number of cell cycles, lead to the concensus that DNA demethylation in PGCs was an active process. The protein activation-induced deaminase ( $\mathrm{Aid}$ ), has been conclusively shown to be involved in global DNA de-methylation in PGCs, whereas TDG, BER and the TET proteins have been proposed without definitive proof (Seisenberger et al., 2013). There is some evidence to support the possibility that DNA methylation erasure is initiated earlier, at the time of the down regulation of the DNA methylation machinery transcripts (Seki et al., 2005; Kurimoto et al., 2008; Guibert et al., 2012). If the period of global erasure is extended back to this stage, then passive demethylation also becomes a possibility.

\section{Reprogramming of DNA Methylation}

During spermatogenesis and oogenesis, epigenetic modifications are established which are required for normal embryonic progression (Bourc'his et al., 2001; Rideout et al., 2001; O'Doherty et al., 2012). Reprogramming the maternal genome, through appropriate DNA methylation of differentially methylated regions (DMRs), is central in regulating genomic imprinting ( $\mathrm{Li}$ et al., 1993), a process in which a small cohort of genes are exclusively expressed from a single allele, according to parent-of-origin (Preece and Moore, 2000). Imprinted gene DMRs are actively established during mammalian gametogenesis (Reik et al., 2001), the vast majority of which acquire DNA methylation from the maternal germline during the oocyte growth phase (Ueda et al., 1992; Lucifero et al., 2002, 2004; Hiura et al., 2006). During postnatal mouse oogenesis, imprinting establishment occurs asynchronously at different imprinted genes during the transition from primordial to antral follicle stages (Lucifero et al., 2004; Hiura et al., 2006;). The DMRs tested in human and bovine oocytes have shown the expected pattern of methylation (Geuns et al., 2003, 2007; El Hajj et al., 2011; Heinzmann et al., 2011; O'Doherty et al., 2012; Urrego et al.,
2014). However, there appear to be differences in the mechanisms and timings of imprint establishment among mammals, (see review by (Hanna and Kelsey, 2014)). For example, the oocyte growth phase in humans and cattle is quite protracted, lasting months (Fair, 2003; Fair et al., 1997). Acquisition of the maternal imprints commences in the final phase of oocyte growth and the individual imprints appear to be established in a size-specific manner (Geuns et al., 2003, 2007; Arima and Wake, 2006; Sato et al., 2007; O'Doherty et al., 2012). In bovine, for example, acquisition of the maternal imprints commences when oocytes reach a diameter of 110 to $120 \mu \mathrm{m} ; S N R P N$ and MEST are fully methylated by $120 \mu \mathrm{m}$, whereas IGF2R, PEG10 and PLAGL were only partially methylated at this size (O'Doherty et al., 2012). Recent studies have established that gene transcription determines the characteristic DNA methylation landscape of the mature murine oocyte. Indeed it was determined that transcription events could account for $85-90 \%$ of DNA methylation established in the oocyte, including methylated $\mathrm{CpG}$ islands (CGIs) and imprinted DMRs (Veselovska et al., 2015). However, a small number of expressed genes escape DNA methylation, as well as a small number of CGIs within active transcription units. Indeed, it suggests that gene expression perturbations during oocyte follicular growth could result in alterations in DNA methylation in mature gametes, including at CGIs. Since a fraction of the oocyte DNA methylome is maintained to some extent in pre-implantation embryos just before the embryonic onset of de novo methylation, environmentally induced changes in gene expression in female germ cells could lead to alterations in the epigenome of the next generation, with possible transgenerational effects (Borgel et al., 2010; Smallwood et al., 2011). Thus, physiological or external factors that disrupt the transcription environment during oocyte follicular growth could result in alterations in DNA methylation in mature gametes.

Genome-wide studies in human gametes and embryos have revealed many similar mechanisms of global DNA methylation reprogramming between humans and mice (Guo et al., 2014; Smith et al., 2014). Imprinting marks must be maintained during the sensitive oocyte-to-embryo transition. As this stage of development is under maternal control, the role of maternal effect genes in genomic imprint regulation is of interest. Several key maternal effect proteins that protect imprinted methylation sites during preimplantation development have been identified and include: PGC7 (also known as STELLA or DPPA3): In mice, PGC7 was shown to maintain imprints at a subset of loci, including Pegl, Peg3, and Peg10 domains and the paternally imprinted H19-Igf2 (H19DMR) and Rasgrfl domains (Nakamura et al., 2007); zinc finger protein 57 (ZFP57), which is required for the methylation of the Snrpn domain in mouse oocytes and for the maintenance of DNA methylation after fertilisation at $D l k 1$, Peg1, Peg3 and Nnat domains (Li et al., 2008); tripartite motif-containing 28 protein (TRIM28; also known as KAP1/TIF1b), TRIM28 may regulate epigenetic stability in mouse oocytes and embryos by protecting against passive demethylation (Messerschmidt et al., 2012) and finally, DNMT1 (Hirasawa et al., 2008). Two DNMT1 isoforms are present in mature oocytes and preimplantation embryos: oocyte-specific (DNMT1o) and somatic (DNMT1s) isoforms. DNMT1o accumulates during oocyte growth (Bao et al., 2000), and is the abundant form expressed in oocytes and preimplantation embryos (Mertineit et al., 1998). There are five known family members of the DNMTS (DNMT1, DNMT2, DNMT3A, DNMT3B AND DNMT3L), which are believed to be responsible for establishing and maintaining methylation patterns (Ooi et al., 2009). Gene targeting studies in mice have demonstrated that the methyltransferases DNMT3A, DNMT3B and DNMT1 are indispensable for 
embryonic survival (Li et al., 1992; Okano et al., 1999). These findings are likely to apply also in cattle, as we have demonstrated the presence of DNMT3A, DNMT3B and DNMT3L in bovine oocytes during the critical period of DNA methylation imprint acquisition (O'Doherty et al., 2012). Although not addressed here, it must be recognized that additional epigenetic modifications that are established in the oocyte, such as histone post-transcriptional modifications that signal active and silent chromatin and regulatory elements, also impact on decisions in the early embryo and any alterations or failures could lead to impaired epigenetic quality of the oocyte that might impact on early embryonic development and longer-term health.

\section{Epigenetic effect of maternal physiological status on embryo and foetal-oocyte programming and adult offspring health}

The protracted nature of oocyte growth in bovine and humans could result in repeated exposure of oocytes to environmental challenges, resulting in an accumulation of insults over the lifetime of the female. For example, it is likely that most females will experience alterations to their diet and nutritional status, development of metabolic and/ or infectious disease, exposure to environmental toxins and stress and in some cases administration of assisted reproductive therapies during their lives. Since an important fraction of the oocyte DNA methylome is maintained during preimplantation embryogenesis, environmentally-induced changes in gene expression in oocytes could lead to alterations in the epigenome of the next generation.

There is substantial evidence that the maternal environment pre-conception and during embryonic and foetal development, including inadequate nutrition and overnutrition, influences the development and future health of the individual (Barker et al., 1989). The condition, health status and age of the oocyte donor (mother) can affect the quality of the oocyte and the health of the resulting offspring (Ashworth et al., 2009). This is especially relevant to the fertility of European women, where the average age at which women deliver their first child has increased to almost 30 years (http://www.unpopulation.org; 2014, United Nations Population Division Department of Economic and Social Affairs). The mechanisms behind these effects are unknown, but most likely alteration of gene expression in the oocyte and surrounding follicle cells, is instrumental. Studies in mice (Dahlhoff et al., 2014) and cattle (O'Doherty et al., 2014), have shown that DNA methylation in oocytes is modified by maternal diet or physiology. Postpartum lactating dairy cows are frequently pathogenically and metabolically challenged due to preferential partitioning of energy to milk production, leading to poor reproductive performance within their critical re-breeding window. The adverse metabolic environment induced by lactation alters the metabolomic, steroidogenic and transcriptomic profile of ovarian follicles during their development in postpartum lactating cows compared to nonlactating heifers (Bender et al., 2010; Walsh et al., 2012a, b). Metabolic differences include higher concentrations of saturated and lower concentrations of poly unsaturated -fatty acids and altered amino acid profiles in follicular fluid from lactating cows compared to those from dry heifers (Bender $e t$ al., 2010). Steroidogenesis is also compromised; dominant follicle estradiol and progesterone synthesis is reduced during differentiation and luteinization, respectively (Walsh et al., $2012 b$ ). At the level of the transcriptome the expression profiles of transcripts associated with steroid biosynthesis (Walsh et al., 2012b), immune cell function and chemotaxis (Walsh et al., 2012b) are also different. We have analysed the methylation status of a several candidate imprinted DMRs in fully-grown oocytes from postpartum cows. The resulting data revealed hypomethylation at the DMRs of a number of maternally methylated imprinted genes (PEG3, PLAGL1 and $S N R P N$ ), in oocytes recovered from postpartum cows during the period of most acute negative energy balance (NEB) and greatest metabolic stress. The contribution of an inappropriate follicular fluid fatty acid profile to the aberrant methylation status was investigated in vitro. The findings confirmed the sensitivity of PLAG1 to the follicular environment (O'Doherty et al., 2014). The most famous comparative situation in humans is the Dutch winter famine cohort; specifically, individuals conceived during famine presented hypomethylation of the IGF2-DMR compared with their nonexposed siblings, almost sixty years after exposure (Heijmans et al., 2008). Furthermore, genome-wide analysis of DMRs in the cohort detected a number of differentially methylated $\mathrm{CpG}$ regions, usually at regulatory regions (Ravelli et al., 1998; Oger et al., 2014). Moreover, the findings of an additional study indicated that the nutrition-dependent changes in methylation were gene- or tissue-restricted (Veenendaal et al., 2012). While NEB is a highly important issue for high yielding postpartum dairy cows, most Western societies do not expect to ever experience a scenario like the Dutch winter famine; obesity and high glycemic diets are possibly the most significant issues facing western women. Obesity induces multiple changes in the ovary, such as leptin resistance, lipotoxicity and local inflammation, all of which could have an impact on processes involved in establishment of the oocyte's normal epigenetic programme. There is much concern that maternal obesity and associated complications during early embryo life leave a "nutritional imprint" with long-term effects on the promotion of obesity and related conditions in adulthood (Ravelli et al., 1998). Data from animal models fed high fat diets clearly endorses the validity of these concerns. Consumption of a high fat (HF) diet during gestation ( $35-60 \%$ of calories from fat) is associated with offspring obesity, hypertension, abnormal cholesterol metabolism and cardiovascular disease, for review see Seki et al., 2012). Several rodent models have been employed to investigate the epigenetic changes induced by a maternal HF diet. Results from a selection of models demonstrate that a HF diet during pregnancy can induce epigenetic modification, including changes in DNMT expression (Liu et al., 2011; Zhou and Pan, 2011), altered DNA methylation of genes involved in obesity, and energy homeostasis (Martínez et al., 2014) hypomethylation of the $M c 4 r$ gene, which plays a role in body weight regulation in mice (Gong et al., 2010); and altered transcription and methylation status of $I g f-2$ in fetal livers from dams fed HF diets (van Straten et al., 2010). Obviously studies on human tissues are more restrictive, however, recent studies employing genome-wide epigenetic analysis also revealed the potential for widespread DNA methylation variation in foetal tissues exposed to maternal gestational diabetes (Finer et al., 2015).

\section{Extra-ovarian factors affecting oocyte development: The effect of Assisted Reproductive Technologies (ART) Research:}

Assisted reproduction technologies are now responsible for the birth of tens of thousands of children yearly and up to $2 \%$ of all births in some countries (2004). A growing number of human and animal model studies have indicated the likely presence of postnatal consequences of ART and infertility, some associated with epigenetic alterations in conceptuses and placentae (Walter and Paulsen, 2003; Nelissen et al., 2014; Whitelaw et al., 2014). Ovarian 
hyperstimulation has been associated with alterations in global DNA methylation levels in two-cell mouse embryos and reduced pre-implantation development in vitro (Shi and Haaf, 2002). The majority of mouse studies have found no effects on imprinting establishment, although several reports indicate that ovarian stimulation might interfere with the capacity to maintain imprinting during pre-implantation development, for review see Anckaert and Fair, 2015). In the human population, there have been reports of an increased risk for certain imprinting disorders following ART (Huntriss and Picton, 2008). These involved cases of Beckwith-Wiedemann Syndrome, Silver-Russell Syndrome and Angelman Syndrome. In addition to epigenetic defects localized to specific genes, alterations have also been observed at additional loci (Rossignol et al., 2006), suggesting a more global epigenetic disruption after assisted reproduction in humans. These concerns are reinforced by the detection of changes in both the epigenome and transcriptome in physiologically normal ART offspring (Batcheller et al., 2011).

There is much endeavor to expand the range of ARTs offered to patients to include ovarian cortical cryopreservation and subsequent retransplantation or in vitro culture to patients facing ovarian toxic chemotherapy. While there has been some progress (Laronda et al., 2014), currently, there is no data available to measure the epigenetic impact of such treatments on the cultured oocyte or resulting embryo. The findings from studies in mice suggest that the oocyte imprint establishment during in-vitro follicle culture conditions progresses normally (Anckaert et al., 2009, 2013; Hiura et al., 2006; Lucifero et al., 2002, 2004; Trapphoff et $a l ., 2010)$ and candidate imprints were not perturbed in twocell embryos obtained after IVF of oocytes derived from the same in-vitro follicle system (El Hajj et al., 2011), however, in vitro culture of the resulting embryos was associated with loss of imprinting for several genes in fetal and placental tissues (Mann et al., 2004; Rivera et al., 2008). This might indicate a different susceptibility of the in vitro grown and matured oocyte compared to the embryo, to culture-induced effects. Furthermore, care needs to be taken when extrapolating mouse data to support ART interventions in humans, as discussed above, the protracted natured of oocyte growth and the extended residency of the oocyte in the human ovary, may result in increased opportunities or sensitivity to aberrant epigenetic programming.

In cattle, research into developmental epigenetics has primarily focused on cloned bovine embryos, due to the high degree of pregnancy loss following transfer of embryos produced by somatic cell nuclear transfer (SCNT; ChavattePalmer et al., 2012). Nevertheless, evidence does exist to indicate that embryos produced by more conventional ART protocols are also susceptible to erroneous epigenetic programming (Urrego et al., 2014, for review). Global methylation profiling of bovine embryos revealed remarkable differences in the DNA methylation profile of blastocysts depending on developmental stages completed under in vitro culture condition. Furthermore, DNA methylation patterns of $\mathrm{CpG}$ islands and repetitive elements were also affected in the blastocysts depending on the stage of the embryo subjected to in vitro culture (Salilew-Wondim et al., 2015). Moreover, the data from cattle is supported by the extensive body of work describing differences at the gross morphological, ultrastructural, physiological, chromosomal, transcriptional and metabolic levels in in vitro-derived embryos compared with their in vivo-derived counterparts (reviewed in Lonergan and Fair 2008; Anckaert and Fair, 2015).

\section{Conclusion}

The regulation of oocyte and embryo development is a highly orchestrated, multi-regulatory process. DNA methylation is an important epigenetic regulatory mechanism. The prolonged growth phase and residency within the ovary endured by oocytes from larger mammals means that multiple opportunities for exposure to potential environmental hazard exists. Therefore it is important that in so far as possible, optimal physiological and external environments are achieved, through dietary management, health care and benign ex vivo assisted reproduction interventions.

\section{References}

Anckaert E, Adriaenssens T, Romero S, Dremier S, Smitz J. 2009. Unaltered imprinting establishment of key imprinted genes in mouse oocytes after in vitro follicle culture under variable follicle-stimulating hormone exposure. Int J Dev Biol, 53:541-548.

Anckaert E, De Rycke M, Smitz J. 2013. Culture of oocytes and risk of imprinting defects. Human Reprod Update, 19:52-66.

Anckaert E, Fair T. 2015. DNA methylation reprogramming during oogenesis and interference by reproductive technologies: Studies in mouse and bovine models. Reprod Fertil Dev, 27:739-754.

Arima T, Wake N. 2006. Establishment of the primary imprint of the HYMAI/PLAGL1 imprint control region during oogenesis. Cytogenet Genome Res, 113:247-252.

Ashworth CJ, Toma LM, Hunter MG. 2009. Nutritional effects on oocyte and embryo development in mammals: implications for reproductive efficiency and environmental sustainability. Philos Trans $R$ Soc Lond B Biol Sci, 364:3351-3361.

Bao S, Obata Y, Carroll J, Domeki I, Kono T. 2000. Epigenetic modifications necessary for normal development are established during oocyte growth in mice. Biol Reprod, 62:616-621.

Barker DJP, Osmond C, Winter P D, Margetts B, Simmonds SJ. 1989. Originally published as volume 2, issue 8663: weight in infancy and death from ischaemic heart disease. Lancet, 334:577-580.

Barton SC, Arney KL, Shi W, Niveleau A, Fundele R, Surani MA, Haaf T. 2001. Genome-wide methylation patterns in normal and uniparental early mouse embryos. Hum Mol Genet, 10:2983-2987.

Batcheller A, Cardozo E, Maguire M, DeCherney AH, Segars J. 2011. Are there subtle, genome-wide epigenetic alterations in normal offspring conceived from assisted reproductive technologies? Fertil Steril, 96:1306-1311.

Bender K, Walsh S, Evans ACO, Fair T, Brennan L. 2010. Metabolite concentrations in follicular fluid may explain differences in fertility between heifers and lactating cows. Reproduction, 139:1047-1055.

Borgel J, Guibert S, Li Y, Chiba H, Schubeler D, Sasaki H, Forne T, Weber M. 2010. Targets and dynamics of promoter DNA methylation during early mouse development. Nat Genet, 42:1093-1100.

Bourc'his D, Xu G L Lin C S, Bollman B, Bestor TH. 2001. Dnmt3L and the establishment of maternal genomic imprints. Science, 294:2536-2539.

Chavatte-Palmer P, Camous S, Jammes H, Le Cleac'h N, Guillomot M, Lee RS. 2012. Review: placental perturbations induce the developmental 
abnormalities often observed in bovine somatic cell nuclear transfer. Placenta, 33(suppl):S99-S104.

Dahlhoff M, Pfister S, Blutke A, Rozman J, Klingenspor M, Deutsch M J, Rathkolb B, Fink B, Gimpfl M, Hrabě de Angelis M, Roscher AA, W olf E, Ensenauer R. 2014. Peri-conceptional obesogenic exposure induces sex-specific programming of disease susceptibilities in adult mouse offspring. Biochim Biophys Acta, 1842:304-317.

Davies W, Isles $A$, Smith $\mathbf{R}$, Karunadasa $\mathbf{D}$, Burrmann D, Humby T, Ojarikre O, Biggin C, Skuse D, Burgoyne P, Wilkinson L. 2005. Xlr3b is a new imprinted candidate for X-linked parent-of-origin effects on cognitive function in mice. Nat Genet, 37:625-629.

Davis TL, Yang GJ, McCarrey JR, Bartolomei MS. 2000. The H19 methylation imprint is erased and re-established differentially on the parental alleles during male germ cell development. Hum Mol Genet, 9:2885-2894

EI Hajj N, Trapphoff T, Linke M, May A, Hansmann T, Kuhtz J, Reifenberg K, Heinzmann J, Niemann H, Daser A, Eichenlaub-Ritter U, Zechner U, Haaf T. 2011. Limiting dilution bisulfite (pyro)sequencing reveals parent-specific methylation patterns in single early mouse embryos and bovine oocytes. Epigenetics, 6:1176-1188.

Fair T, Hulshof S C, Hyttel P, Greve T, Boland M. 1997. Oocyte ultrastructure in bovine primordial to early tertiary follicles. Anat Embryol (Berl), 195:327-336.

Fair T. 2003. Follicular oocyte growth and acquisition of developmental competence. Anim Reprod Sci, 78:203-216.

Finer S, Mathews C, Lowe R, Smart M, Hillman S, Foo L, Sinha A, Williams D, Rakyan V K, Hitman GA. 2015. Maternal gestational diabetes is associated with genome-wide DNA methylation variation in placenta and cord blood of exposed offspring. Hum Mol Genet, 24:3021-3029.

Fowden AL, Sibley C, Reik W, Constancia M. 2006. Imprinted genes, placental development and fetal growth. hormone research in paediatrics. Horm Res, 65(suppl. 3):50-58.

Geuns E, De Rycke M, Van Steirteghem A, Liebaers I. 2003. Methylation imprints of the imprint control region of the SNRPN-gene in human gametes and preimplantation embryos. Hum Mol Genet, 12:28732879.

Geuns E, Hilven P, Van Steirteghem A, Liebaers I, De Rycke M. 2007. Methylation analysis of KvDMR1 in human oocytes. J Med Genet, 44:144-147.

Ginsburg M, Snow MH, McLaren A. 1990. Primordial germ cells in the mouse embryo during gastrulation. Development, 110 521-528.

Guibert S, Forné T, Weber M. 2012. Global profiling of DNA methylation erasure in mouse primordial germ cells. Genome Res, 22:633-641.

Guo H, Zhu P, Yan L, Li R, Hu B, Lian Y, Yan J, Ren X, Lin S, Li J, Jin X, Shi X, Liu P, Wang X, Wang W, Wei Y, Li X, Guo F, Wu X, Fan X, Yong J, Wen L, Xie S,X, Tang F, Qiao J. 2014. The DNA methylation landscape of human early embryos. Nature,

\section{1:606-610.}

Hajkova P, Erhardt S, Lane N, Haaf T, El-Maarri O, Reik W, Walter J, Surani MA. 2002. Epigenetic reprogramming in mouse primordial germ cells. Mech Dev, 117:15-23.

Hales BF, Grenier L, Lalancette C, Robaire B. 2011. Epigenetic programming: from gametes to blastocyst. Birth Defects Res A Clin Mol Teratol, 91:652-665.

Hanna CW, Kelsey G. 2014. The specification of imprints in mammals. Heredity (Edinb), 113:176-183.

Heijmans BT, Tobi EW, Stein AD, Putter H, Blauw GJ, Susser ES, Slagboom PE, Lumey LH. 2008. Persistent epigenetic differences associated with prenatal exposure to famine in humans. Proc Natl Acad Sci USA, 105:17046-17049.

Heinzmann J, Hansmann T, Herrmann D, Wrenzycki C, Zechner U, Haaf T, Niemann H. 2011. Epigenetic profile of developmentally important genes in bovine oocytes. Mol Reprod Dev, 78:188-201.

Hirasawa R, Chiba H, Kaneda M, Tajima S, Li E, Jaenisch R, Sasaki H. 2008. Maternal and zygotic Dnmt1 are necessary and sufficient for the maintenance of DNA methylation imprints during preimplantation development. Genes Dev, 22:1607-1616.

Hiura H, Obata Y, Komiyama J, Shirai M, Kono T. 2006. Oocyte growth-dependent progression of maternal imprinting in mice. Genes Cells, 11:353-361.

Huntriss J, Picton HM. 2008. Epigenetic consequences of assisted reproduction and infertility on the human preimplantation embryo. Hum Fertil (Camb), 11:85-94

Kurimoto K, Yabuta Y, Ohinata Y, Shigeta M, Yamanaka K, Saitou M. 2008. Complex genome-wide transcription dynamics orchestrated by Blimp1 for the specification of the germ cell lineage in mice. Genes Dev, 22:1617-1635.

Gong L, Pan YX, Chen H. 2010. Gestational low protein diet in the rat mediates Igf2 gene expression in male offspring via altered hepatic DNA methylation. Epigenetics, 5:619-626.

Laronda MM, Duncan FE, Hornick JE, Xu M, Pahnke JE, Whelan KA, Shea LD, Woodruff TK. 2014. Alginate encapsulation supports the growth and differentiation of human primordial follicles within ovarian cortical tissue. J Assist Reprod Genet, 31:10131028.

Li E, Bestor TH, Jaenisch R. 1992. Targeted mutation of the DNA methyltransferase gene results in embryonic lethality. Cell, 69:915-926.

Li E, Beard C, Jaenisch R. 1993. Role for DNA methylation in genomic imprinting. Nature, 366:362365.

Li JY, Lees-Murdock DJ, Xu GL, Walsh CP. 2004. Timing of establishment of paternal methylation imprints in the mouse. Genomics, 84:952-960.

Li X, Ito M, Zhou F, Youngson N, Zuo X, Leder P, Ferguson-Smith AC. 2008. A maternal-zygotic effect gene, Zfp57, maintains both maternal and paternal imprints. Dev Cell, 15:547-557.

Liu X, Wang J, Li R, Sun Q, Albrecht E, Zhao R. 2011. Maternal dietary protein affects transcriptional regulation of myostatin gene distinctively at weaning 
and finishing stages in skeletal muscle of Meishan pigs. Epigenetics, 6:899-907.

Lonergan P, Fair T. 2008. In vitro-produced bovine embryos: dealing with the warts. Theriogenology, 69:17-22.

Lucifero D, Mertineit C, Clarke H J, Bestor TH, Trasler JM. 2002. Methylation dynamics of imprinted genes in mouse germ cells. Genomics, 79:530-538.

Lucifero D, Mann MR, Bartolomei MS, Trasler JM. 2004. Gene-specific timing and epigenetic memory in oocyte imprinting. Hum Mol Genet, 13:839-849.

Maher ER, Reik W. 2000. Beckwith-Wiedemann syndrome: imprinting in clusters revisited. $J$ Clin Invest, 105:247-252.

Mann MR, Lee SS, Doherty AS Verona RI, Nolen LD, Schultz RM, Bartolomei MS. 2004. Selective loss of imprinting in the placenta following preimplantation development in culture. Development, 131:3727-3735.

Martínez AJ, Milagro FI, Claycombe KJ, Schalinske KL. 2014. Epigenetics in Adipose Tissue, Obesity, Weight Loss, and Diabetes. Adv Nutr, 5:71-81.

Mertineit C, Yoder JA, Taketo T, Laird DW, Trasler JM, Bestor TH. 1998. Sex-specific exons control DNA methyltransferase in mammalian germ cells. Development, 125:889-897.

Messerschmidt DM, de Vries W, Ito M, Solter D, Ferguson-Smith A, Knowles BB. 2012. Trim28 is required for epigenetic stability during mouse oocyte to embryo transition. Science, 335:1499-1502.

Morgan HD, Santos F, Green K, Dean W, Reik W. 2005. Epigenetic reprogramming in mammals. Hum Mol Genet, 14:R47-R58.

Nakamura T, Arai Y, Umehara H, Masuhara M, Kimura T, Taniguchi H, Sekimoto T, Ikawa M, Yoneda Y, Okabe M, Tanaka S, Shiota K, Nakano T. 2007. PGC7/Stella protects against DNA demethylation in early embryogenesis. Nat Cell Biol, 9:64-71.

Nelissen EC, Dumoulin JC, Busato F, Ponger L, Eijssen LM, Evers JL, Tost J, van Montfoort AP. 2014. Altered gene expression in human placentas after IVF/ICSI. Hum Reprod, 29:2821-2831.

O'Doherty AM, O'Shea LC, Fair T. 2012. Bovine DNA Methylation imprints are established in an oocyte size-specific manner, which are coordinated with the expression of the DNMT3 family proteins. Biol Reprod, 86:67

O'Doherty AM, O'Gorman A, al Naib A, Brennan L, Daly E, Duffy P, Fair T. 2014. Negative energy balance affects imprint stability in oocytes recovered from postpartum dairy cows. Genomics, 104:177-185.

Oger F, Dubois-Chevalier J, Gheeraert C, Avner S, Durand E, Froguel P, Salbert G, Staels B, Lefebvre P, Eeckhoute J. 2014. Peroxisome proliferatoractivated receptor $\gamma$ regulates genes involved in insulin/insulin-like growth factor signaling and lipid metabolism during adipogenesis through functionally distinct enhancer classes. J Biol Chem, 289:708-722.

Ohinata Y, Ohta H, Shigeta M, Yamanaka K, Wakayama T, Saitou M. 2009. A signaling principle for the specification of the germ cell lineage in mice. Cell, 137:571-584

Okano M, Bell D W, Haber DA, Li E. 1999. DNA
Methyltransferases Dnmt3a and Dnmt3b are essential for de novo methylation and mammalian development. Cell, 99:247-257.

Ooi S KT, O'Donnell A H, Bestor TH. 2009. Mammalian cytosine methylation at a glance. J Cell Sci, 122:2787-2791.

Oswald J, Engemann S, Lane N, Mayer W, Olek A, Fundele R, Dean W, Reik W, Walter J. 2000. Active demethylation of the paternal genome in the mouse zygote. Curr Biol, 10:475-478.

Preece MA and Moore GE. 2000. Genomic imprinting, uniparental disomy and foetal growth. Trends Endocrinol Metab. 11:270-275.

Proudhon C, Duffie R, Ajjan S, Cowley M, Iranzo J, Carbajosa G, Saadeh H, Holland ML, Oakey RJ, Rakyan VK, Schulz R, Bourc'his D. 2012. Protection against de novo methylation is instrumental in maintaining parent-of-origin methylation inherited from the gametes. Mol Cell, 47:909-920.

Ravelli ACJ, van der Meulen JHP, Michels RPJ, Osmond C, Barker DJP, Hales CN, Bleker OP. 1998. Glucose tolerance in adults after prenatal exposure to famine. Lancet, 351:173-177.

Reik W, Dean W, Walter J. 2001. Epigenetic reprogramming in mammalian development. Science, 293:1089-1093.

Reik W, Walter J. 2001. Genomic imprinting: parental influence on the genome. Nat Rev Genet, 2:21-32.

Rideout WM 3rd, Eggan K, Jaenisch R. 2001. Nuclear cloning and epigenetic reprogramming of the genome. Science, 293:1093-1098.

Rivera RM, Stein P, Weaver J R, Mager J, Schultz RM, Bartolomei MS. 2008. Manipulations of mouse embryos prior to implantation result in aberrant expression of imprinted genes on day 9.5 of development. Hum Mol Genet, 17:1-14.

Rossignol S, Steunou V, Chalas C, Kerjean A, Rigolet M, Viegas-Pequignot E, Jouannet P, Bouc YL, Gicquel C. 2006. The epigenetic imprinting defect of patients with Beckwith-Wiedemann syndrome born after assisted reproductive technology is not restricted to the 11 p15 region. J Med Genet, 43:902-907.

Rutledge CE, Thakur A, O'Neill K M, Irwin RE, Sato S, Hata K, Walsh CP. 2014. Ontogeny, conservation and functional significance of maternally inherited DNA methylation at two classes of nonimprinted genes. Development, 141:1313-1323.

Salilew-Wondim D, Fournier E, Hoelker M, SaeedZidane M, Tholen E, Looft C Neuhoff C, Besenfelder U, Havlicek V, Rings F, Gagné D, Sirard MA, Robert C, Shojaei Saadi HA, Gad A, Schellander K, Tesfaye D. 2015. Genome-wide DNA methylation patterns of Bovine blastocysts developed in vivo from embryos completed different stages of development in vitro. PLoS One, 10:e0140467.

Sato A, Otsu E, Negishi H, Utsunomiya T, Arima $T$. 2007. Aberrant DNA methylation of imprinted loci in superovulated oocytes. Hum Reprod, 22:26-35.

Seisenberger S, Peat JR, Hore TA, Santos F, Dean W, Reik W. 2013. Reprogramming DNA methylation in the mammalian life cycle: building and breaking epigenetic barriers. Philos Trans $R$ Soc B Biol Sci, 


\section{8:20110330.}

Seki Y, Hayashi K, Itoh K, Mizugaki M, Saitou M, Matsui Y. 2005. Extensive and orderly reprogramming of genome-wide chromatin modifications associated with specification and early development of germ cells in mice. Dev Biol, 278:440-458.

Seki Y, Williams L, Vuguin PM, Charron MJ. 2012. Minireview: epigenetic programming of diabetes and obesity: animal models. Endocrinology, 153:1031-1038. Shi W, Haaf T. 2002. Aberrant methylation patterns at the two-cell stage as an indicator of early developmental failure. Mol Reprod Dev, 63:329-334.

Smallwood SA, Tomizawa S, Krueger F, Ruf N, Carli N, Segonds-Pichon A, Sato S, Hata K, Andrews SR, Kelsey G. 2011. Dynamic CpG island methylation landscape in oocytes and preimplantation embryos. Nat Genet, 43:811-814.

Smith FM, Garfield AS, Ward A. 2006. Regulation of growth and metabolism by imprinted genes. Cytogenet Genome Res, 113:279-291.

Smith LC, Suzuki J Jr, Goff AK, Filion F, Therrien J, Murphy B D, Kohan-Ghadr H R, Lefebvre R, Brisville A C, Buczinski S, Fecteau G, Perecin F, Meirelles FV. 2012. Developmental and epigenetic anomalies in cloned cattle. Reprod Domest Anim, 47(suppl. 4):107-114.

Smith ZD, Chan MM, Humm KC, Karnik R, Mekhoubad S, Regev A, Eggan K, Meissner A. 2014. DNA methylation dynamics of the human preimplantation embryo. Nature, 511:611-615.

Torres-Padilla M E, Ciosk R. 2013. A germlinecentric view of cell fate commitment, reprogramming and immortality. Development, 140:487-491.

Trapphoff T, El Hajj $\mathbf{N}$, Zechner U, Haaf $T$, Eichenlaub-Ritter U. 2010. DNA integrity, growth pattern, spindle formation, chromosomal constitution and imprinting patterns of mouse oocytes from vitrified pre-antral follicles. Hum Reprod, 25:3025-3042.

Ueda T, Yamazaki K, Suzuki R, Fujimoto H, Sasaki H, Sakaki Y, Higashinakagawa T. 1992. Parental methylation patterns of a transgenic locus in adult somatic tissues are imprinted during gametogenesis. Development, 116:831-839.

Urrego R, Rodriguez-Osorio N, Niemann H. 2014. Epigenetic disorders and altered gene expression after use of Assisted Reproductive Technologies in domestic cattle. Epigenetics, 9:803-815.

van Straten EM, Bloks VW, Huijkman NC, Baller JF, van Meer H, Lütjohann D, Kuipers F, Plösch T. 2010. The liver X-receptor gene promoter is hypermethylated in a mouse model of prenatal protein restriction. Am J Physiol Regul Integr Comp Physiol, 298:R275-R282.

Veenendaal MV, Costello PM, Lillycrop KA, de Rooij SR, van der Post JA, Bossuyt PM, Hanson MA, Painter RC, Roseboom TJ. 2012. Prenatal famine exposure, health in later life and promoter methylation of four candidate genes. $J$ Dev Orig Health Dis, 3:450-457.

Veselovska L, Smallwood SA, Saadeh H, Stewart KR, Krueger F, Maupetit-Méhouas S, Arnaud P, Tomizawa S, Andrews S, Kelsey G. 2015. Deep sequencing and de novo assembly of the mouse oocyte transcriptome define the contribution of transcription to the DNA methylation landscape. Genome Biol, 16:209.

Walsh SW, Fair T, Browne JA, Evans ACO, McGettigan PA. 2012a. Physiological status alters immunological regulation of bovine follicle differentiation in dairy cattle. J Reprod Immunol, 96:34-44.

Walsh SW, Mehta JP, McGettigan PA, Browne JA, Forde N, Alibrahim RM, Mulligan FJ, Loftus B, Crowe MA, Matthews D, Diskin M, Mihm M, Evans ACO. 2012b. Effect of the metabolic environment at key stages of follicle development in cattle: focus on steroid biosynthesis. Physiol Genomics, 44:504-517.

Walter J, Paulsen M. 2003. Imprinting and disease. Semin Cell Dev Biol, 14:101-110.

Whitelaw N, Bhattacharya S, Hoad G, Horgan G W, Hamilton M, Haggarty P. 2014. Epigenetic status in the offspring of spontaneous and assisted conception. Hum Reprod, 29:1452-1458.

Wu SC, Zhang Y. 2010. Active DNA demethylation: many roads lead to Rome. Nat Rev Mol Cell Biol, 11:607-620.

Xu GL, Walsh CP. 2014. Enzymatic DNA oxidation: mechanisms and biological significance. BMB Rep, 47:609-618.

Zhou D, Pan YX. 2011. Gestational low protein diet selectively induces the amino acid response pathway target genes in the liver of offspring rats through transcription factor binding and histone modifications. Biochim Biophys Acta, 1809:549-556. 